\title{
A paradiplomacia na dinâmica contemporânea da América do Sul: 0 caso das mercocidades
}

\author{
Autora: Jéssica Gomes de Jesus (IC) / Orientadora: Claudete de Castro Silva Vitte
}

\begin{abstract}
Resumo
No atual cenário das relações internacionais ocorreu a emergência dos governos subnacionais que passaram a atuar no âmbito da política externa. Esse envolvimento dos entes não-centrais é denominado de paradiplomacia e é o processo estudado por essa pesquisa. Nosso principal objetivo foi contribuir no entendimento acerca da inserção dos governos locais na dinâmica internacional contemporânea da América do Sul. O objeto de estudo é a atuação paradiplomática da Rede Mercocidades, que é uma rede horizontal de municípios pertencentes ao Mercosul. A metodologia adotada envolveu revisão bibliográfica, consultas eletrônicas aos jornais e coleta de dados e informações no site institucional da Rede. A hipótese norteadora desse trabalho foi comprovada, pois a paradiplomacia não é um risco a soberania estatal, mas uma forma eficaz dos agentes subnacionais solucionarem suas demandas. Concluimos que a Rede Mercocidades é um instrumento em potencial para a redução das desigualdades regionais e o principal impasse para sua atuação é a institucionalização da Rede e falta de participação popular.
\end{abstract}

Palavras-chave: Paradiplomacia; Integração regional; Mercocidades.

\section{Introdução}

Segundo Prieto (2004, p.252), a paradiplomacia pode ser definida como "o envolvimento de governos não centrais nas relações internacionais, mediante o estabelecimento de contatos permanente e ad. hoc, com entidades públicas ou privadas estrangeiras, com o objetivo de promoção socioeconômica e cultural, bem como de qualquer outra dimensão exterior nos limites de sua competência institucional".

O Mercado Comum do Cone Sul (Mercosul) foi fundado em 1995 pelo Tratado de Assunção e é formado por Argentina, Brasil, Paraguai, Uruguai e Venezuela. Além dos países-membros, possui como países associados Bolívia, Chile e Peru. Já a Rede Mercocidades foi criada em 1995 e integra atualmente 303 cidades. Trata-se de uma rede horizontal que possui o objetivo de inserir as localidades no processo de integração regional, favorecendo a cooperação e a troca de experiências entre os integrantes.

A Rede de Mercocidades é um exemplo do fenômeno da paradiplomacia na América do Sul, no qual as cidades incluem suas necessidades individuais à agenda do Mercosul. A intenção desses municípios é criar uma nova rede de relações diretas com os outros países, auxiliando na busca de melhorias internas.

\section{Resultados e Discussão}

Ao longo da pesquisa consultamos jornais por via eletrônica com a finalidade de verificar a percepção da sociedade quanto aos mecanismos adotados pelos governos locais no âmbito da política externa. Constatamos que apesar dos 20 anos da Rede e o fato da cidade de São Paulo ser sua atual presidente, a mídia brasileira, em geral, não trata sobre esse tema e as notícias são vinculadas pelos sites institucionais.

Sobre as temáticas das agendas paradiplomáticas das cidades mercosulinas, há enfoque em acordos de importação e exportação, atração de investimentos estrangeiros, turismo e relações entre as fronteiras.

O maior problema enfrentado pelos governos subnacionais é da institucionalização de seus acordos, uma vez que em países federados os entes subnacionais não podem fazer política externa, sendo esta delegada ao governo central (Ministério de Relações Exteriores e instituições correlatas).

\section{Conclusões}

Concluímos que a Rede Mercocidades é um instrumento em potencial para reduzir as desigualdades regionais, uma vez que os governos locais podem inserir suas demandas na agenda do Mercosul. Entretanto, há impasses como o reconhecimento jurídico-institucional dessa rede de cidades e, efetivamente, maior participação popular, com a inclusão das demandas da sociedade na agenda do Mercosul.

\section{Agradecimentos}

Agradecemos ao apoio do Conselho Nacional de Desenvolvimento Científico e Tecnológico (CNPQ).

${ }^{1}$ PRIETO, N.C. O outro lado do novo regionalismo pós-soviético e da Ásia-Pacífico: a diplomacia federativa além das fronteiras do mundo ocidental. In: VIGEVANI, T. et. al. (orgs). A dimensão subnacional e as relações internacionais. São Paulo: EDUC; UNESP/EDUSC, 2004. p. 251-282. 